\title{
MERGERS AND ACQUISITIONS ROLE TOWARDS SHAREHOLDERS' WEALTH IN THE BANKING SECTOR OF PAKISTAN
}

\author{
Salar Hussain* \\ Institute of Business Administration, University of Sindh, Jamshoro \\ Department of Business Administration, Shaheed Benzair Bhutto University, \\ Shaheed Benazirabad, Pakistan \\ Dr ImamudDin Khoso \\ Institute of Business Administration, University of Sindh, Jamshoro, Pakistan \\ Dr Fiza Qureshi \\ Institute of Business Administration, University of Sindh, Jamshoro, Pakistan \\ ORCID ID: https://orcid.org/0000-0002-3730-6084 \\ *Corresponding Author
}

\begin{abstract}
Mergers and Acquisitions (M\&As) are considered as useful strategies for the purpose of growth and expansion of businesses. The trend of $M \& A s$ started by the late nineteenth century, this same trend can be foreseen in the financial sector of Pakistan. The objective of this paper was to measure the role of $M \& A s$ on the shareholders' wealth in Pakistan from 2012 to 2017 in the Banking sector of Pakistan. This was done with the help of event study method in two ways. Firstly, the short term effect was analyzed by abnormal and cumulative abnormal returns (CAR) in 91 days windows period which included 45 days pre and 45 days post-performance. Secondly, long term performance was analyzed using Buy-and-Hold Abnormal Returns (BHAR) with estimation windows of 90,180, 270 and 360 days. The results revealed that the postmerger period was significantly positive and market responded positively to the phenomenon of M\&As for banking sector of Pakistan. Outcomes of this paper will be useful for the management and investors for making investment decisions.
\end{abstract}

Key words: Mergers and Acquisitions, Returns, Buy-and-Hold Abnormal Returns, Event study Technique.

Cite this Article: Salar Hussain, ImamudDin Khoso and Fiza Qureshi, Mergers and Acquisitions Role towards Shareholders' Wealth in the Banking Sector of Pakistan, International Journal of Management, 11(12), 2020, pp. 2417-2423.

http://iaeme.com/Home/issue/IJM?Volume=11\&Issue=12 


\section{INTRODUCTION}

Mergers and acquisitions (M\&A) in the academic research has got substantial interest. Most of the empirical researches focus on the stock returns in short term near the announcement days. Fewer studies analyzed the long term performance of stock returns. Previously various efforts has been made to analyze the merger and acquisitions performance in terms and long term so that measurement techniques can be improved and benchmark issues can be handled and to improve the statistics can be improved [1].

For the purpose of expansion or growth organizations need financial resources[2]. Growth can be achieved when organizations launch a new product or service or by expanding operations beyond the already existing resources. Internal and external resources are the two ways to achieve growth [3]. Mostly the business organizations for expansion of their businesses depend on internal resources which are retained earnings. For considerable growth opportunity, organizations must go for external resources if they are limited on the internal resources within organization. Bank loans, partnerships, acquiring other organizations or merging with any other company are the external sources to achieve growth. In the corporate world, M\&As are the rising strategies that are being adopted by the organizations for expanding businesses. And due to the rapid growth this strategy has been adopted by the many organizations, approximately four to five thousand transactions are recorded for M\&A every year in business world

There are various reasons mentioned in the literature for the occurrence of M\&As between organizations. First reason includes organizational synergy, which states that merged company receives greater value than the individual entity[4].Second, this strategy may reduce the expenditures of the combined venture resulting in wealth maximization of shareholders, thirdly, for the survival of firm in the dynamic environment, fourthly, to gain economy of scale and lastly to reduce costs to enhance returns on equity[5].

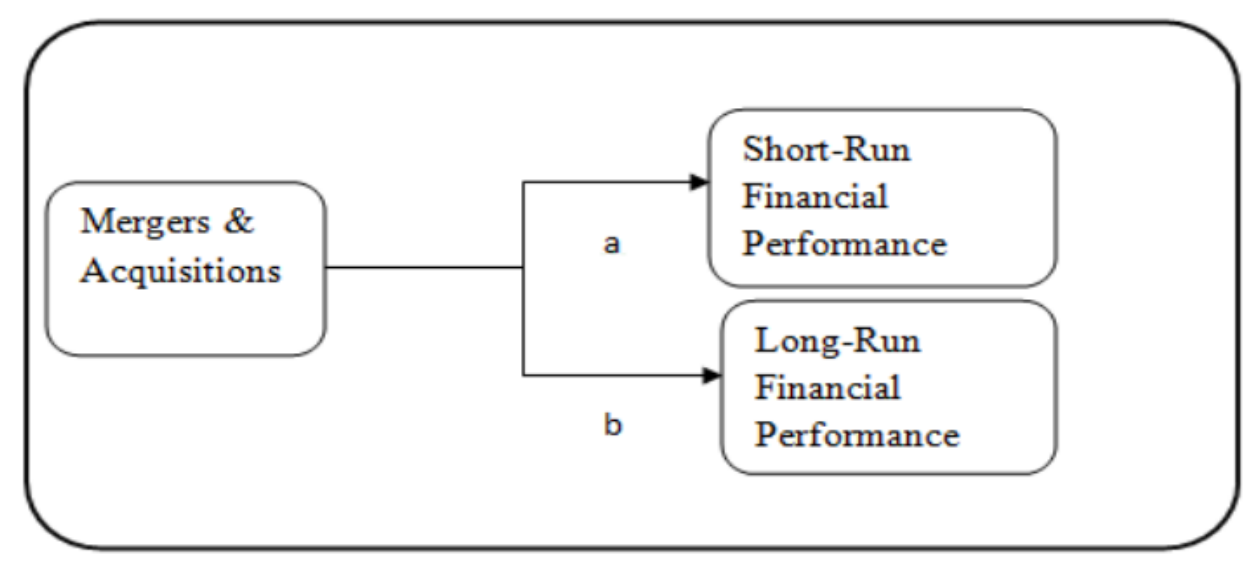

Figure 1

Path a: It will analyze the short-run impact of $M \& A$ s on the stock returns of firms.

Path b: it will assess the financial performance of the firms in the long run.

According to our best estimate, previous literature provides a proof for the occurrence of M\&As in various sectors of the country while for the banking sector of the Pakistan there is adhere need of attention of researchers. These events could have positive, negative or neutral impact on the shareholders wealth in the combined bank. This paper attempts to find out the role of such events on market returns for banking sector of the country, which will be done in two ways, initially this will be analyzed in short run with the help of Abnormal returns and for the long run Buy-and Hold Abnormal returns will be analyzed. The Returns will be analyzed 
for the short-run using event study in which 91 and 11 days estimation windows are selected. In the long run, the data will be analyzed with the help of 90, 180, 270 and 360 days estimation window.

\section{LITERATURE REVIEW}

M\&As strategies have gained the global identity in terms of strategic move in the corporate world over the years. Many national as well as international organizations have successfully opted and adopted these strategies, which has brought significant development to the various sectors in the world[6].

In the developed countries, there is quite recognized and effective system to measure the effects of M\&As, while in the developing countries; there is lack of systems and an issue for the researchers to measure the effects. This is due to the lack of literature regarding events in the developing economies, because of that these events are investigated separately so that the effects of M\&As on financial performance of firms can be calculated [7]. The reasons behind lack of literature can be associated due to various reasons including lack of data, event sources, low usage of these strategies and the scope of M\&As in developing countries[6, 7].

The trend of M\&As in the context of Pakistan is relatively new and has been seen and adopted from only last two decades. Thus, literature in Pakistan is relatively less as compared to other developing or developed countries[8]. That existing literature in Pakistan showed mixed results in terms of market returns. Other studies concluded that there were the positive and significant results while few reported that there was negative or insignificant impact on the share prices.

A study in the manufacturing sector of Pakistan was conducted, in which events from 2000 to 2009 were analyzed. Study concluded that there was the similarity in the results of observed events with the results of other countries events [9]. Another study was conducted by Mehmood et al [10] in which they analyzed banking and pharmaceutical sector of Pakistan. They experienced mixed results, in which few companies had positive effects on share prices while some had negative impact on share prices.

A study was conducted in the Pakistani contest for the banking sector result suggested of M\&As did not provide benefits for all firms except few as most of the M\&As could not provide returns to share holders and their market values declines due to occurrence of events. Further, results suggested that management did not forwarded efficient decision during the phase of M\&As. Lastly, as the results that few of the firms got benefited from the occurrence of events which means there is potential $n$ the banking sector to get benefited from the M\&As so firms must carefully choose and opt for M\&As by critically analyzing the future potential benefits[11].

Another study was conducted in the Pakistani context, in which post M\&As impact was analyzed. In which sample of 8 companies was covered which has gone through the phase of M\&As during the period of 2000-2002. From that sample the most companies belonged to banking and pharmaceutical industry of Pakistan. This was analyzed with the event study technique in which post merger and acquisitions performance was analyzed within one month time frame. Results concluded that five companies had positive and significant results while the two companies had negative impact and one company had no impact on the share prices. Overall, study showed that the M\& positively affected on the share prices of merged companies [10].

M\&As practice is negligible in Pakistan rather than that few studies have been conducted in Pakistani context. A study was conducted by selected the forty five events from the year 2004 to 2010, these events were selected from various sectors of country and were analyzed with the help of event study methodology in the eleven days event window and the results 
concluded that the acquired firms neither created and nor destroyed values for the shareholders[8].

\section{RESEARCH METHODOLOGY}

This study aims to examine the pre and post M\&As performance of the banking sector of Pakistan which took place from the year 2012 to 2017. In this paper, the researcher aims to find out the short term effect of M\&As as well as the long term effect of the M\&As. Short term effect will be studied based on 91 days event period in which 45 days pre and 45 days post-merger performance will be analyzed to calculate expected return, abnormal returns and Cumulative Abnormal Returns of the stocks due to the effect of the announcement of the deals. For this, the market model has been used and stated below.

$$
A R_{i, t}=R_{i, t}-\left(\hat{a}_{i}+\hat{B}_{i} R_{m, t}\right)
$$

Here Ri,t represents the return of the company, in which I represents the company and $t$ shows the trading day. KSE is the Benchmark index, it is shown by Rm,t, and $\alpha \mathrm{i}$ and $\beta \mathrm{i}$ represent the coefficients of regression of the mentioned company. 91 days cays cumulative abnormal return in the 91 days window calculated with the mentioned formula.

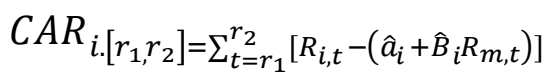

Further, for the long term analysis 90, 180, 270 and 360 days post-merger performance of the acquirer firm's will be analyzed with the help of Buy-and-Hold Abnormal Return[12]. The market-adjusted BHAR can be calculated as:

$$
\operatorname{BHAR}_{i,\left[r_{\left.1, r_{2}\right]}\right]}=\prod_{r_{1}}^{r_{2}}\left(1+R_{i, t}\right)-\prod_{r_{1}}^{r_{2}}\left(1+R_{m . t}\right)
$$

Here Ri,t represents the company return for company $i$ and $t$ represents the trading day. Market returns is shown by Rm,t for KSE 100 index on the day $t$.

Finally, the results of short term analysis as well as long term analyses will be compared so that affectivity of M\&As deals can be analyzed for the banking sector of the country. The deals to be analyzed for the banking sector

\begin{tabular}{|c|c|c|c|}
\hline Event & Acquirer Bank & Target Bank & Event Date \\
\hline E1 & MCB Bank Ltd & NIB Bank Ltd & $07 / 07 / 2017$ \\
\hline E2 & Meezan Bank Ltd & $\begin{array}{l}\text { HSBC Oman (Pakistan } \\
\text { operations) }\end{array}$ & $30 / 09 / 2015$ \\
\hline E3 & Bank Islami Pakistan Ltd & KASB Bank Ltd & $08 / 05 / 2015$ \\
\hline E4 & Meezan Bank Ltd & $\begin{array}{l}\text { HSBC Bank Middle East Limited } \\
\text { (Pakistan operations) }\end{array}$ & $12 / 08 / 2014$ \\
\hline E5 & United Bank Ltd & Khushhali Bank Limited & $11 / 05 / 2012$ \\
\hline
\end{tabular}

The M\&As deals for the banking sector are mentioned in the table below.

Table 1 Events under study

Source of data is Competition Commission of Pakistan and Pakistan Stock Exchange

\section{DATA ANALYSIS}

\subsection{Short term Analysis}

In the events study methodology, Abnormal Returns (ARs) and Cumulative Abnormal Returns (CARs) of the acquired firms are computed with the stock prices and market price 
which are associated with the particular index. These ARs and CARs are effective for measuring the wealth effects on the shareholders' wealth before and after the occurrence of the particular event. The AR is the differences between the expected return and the actual return of the stock. While the CAR is the summation of all the ARs obtained in the event window[13]. For this study the event window has is 91 days in which 45 day pre and 45 days post performance and the announcement date has been analyzed. The estimation window for this study is 100 days which has been taken pre announcement of the event.

The below table shows the results of 5 events which are under study in the banking sector of Pakistan, in which pre performance, event date, post performance of firms and difference between pre and post performance is shown. On the announcement day of the event, the results indicate positive effects on ARs and CARs for the event 1,2 and 4. The event 3 shows the negative abnormal return on the event day while its Cumulative Abnormal Return is positive on the event day. The event 5 show negative returns ARs and CARs for the banking sector after the announcement of M\&As.

Besides, if we look at the differences between pre and post M\&As performance. The ARs and CARs in the events 1, 3 and 5 are positive in the event window of 91 days, while the ARs and CARs for the event 2 is negative, for the event 4 it has positive ARs but negative CARs. The results explain that the three for the five events in the banking sector of Pakistan generated positive ARs and CARs.

This can be concluded that happening of M\&As, positively affected the shareholders' wealth in the banking sector of Pakistan in Short term analysis. These results are matched with results of Flught[14], Soongswang[15] , as they in their studies also reported positive returns by the occurrence of events. Though these results contradict with the results of Cummins and Weiss [16], as they reported negative results after the announcement of M\&As

Table 2 Abnormal Returns (ARs) and cumulative abnormal returns (CARs):

\begin{tabular}{|c|c|c|c|c|c|}
\hline Event & & Event Day & Pre-event & Post- Event & Difference \\
\hline $\begin{array}{l}\text { Event } 1 \text { (MCB } \\
\text { Bank Ltd- NIB }\end{array}$ & Abnormal Return & $0.10 \%$ & $0.15 \%$ & $0.20 \%$ & $0.05 \%$ \\
\hline Bank ltd) & $\begin{array}{l}\text { Cumulative } \\
\text { Abnormal Return }\end{array}$ & $6.80 \%$ & $6.70 \%$ & $8.81 \%$ & $2.11 \%$ \\
\hline $\begin{array}{l}\text { Event } 2 \text { (Meezan } \\
\text { Bank Ltd- HSBC }\end{array}$ & Abnormal Return & $0.64 \%$ & $0.45 \%$ & $-0.43 \%$ & $-0.87 \%$ \\
\hline $\begin{array}{l}\text { Oman (Pakistan } \\
\text { operations)) }\end{array}$ & $\begin{array}{l}\text { Cumulative } \\
\text { Abnormal Return }\end{array}$ & $20.68 \%$ & $20.04 \%$ & $-19.29 \%$ & $-39.33 \%$ \\
\hline $\begin{array}{l}\text { Event } 3 \text { (Bank } \\
\text { Islami Pakistan }\end{array}$ & $\begin{array}{l}\text { Average } \\
\text { Abnormal Return }\end{array}$ & $-2.77 \%$ & $0.25 \%$ & $0.36 \%$ & $0.11 \%$ \\
\hline $\begin{array}{l}\text { Ltd- KASB Bank } \\
\text { Ltd) }\end{array}$ & $\begin{array}{l}\text { Cumulative } \\
\text { Abnormal Return }\end{array}$ & $8.62 \%$ & $11.38 \%$ & $16.17 \%$ & $4.79 \%$ \\
\hline $\begin{array}{l}\text { Event } 4 \text { (Meezan } \\
\text { Bank Ltd -HSBC }\end{array}$ & $\begin{array}{l}\text { Average } \\
\text { Abnormal Return }\end{array}$ & $2.65 \%$ & $0.09 \%$ & $0.03 \%$ & $0.06 \%$ \\
\hline $\begin{array}{l}\text { Bank Middle East } \\
\text { Limited (Pakistan } \\
\text { operations)) }\end{array}$ & $\begin{array}{l}\text { Cumulative } \\
\text { Abnormal Return }\end{array}$ & $6.77 \%$ & $4.12 \%$ & $1.28 \%$ & $-2.84 \%$ \\
\hline $\begin{array}{l}\text { Event } 5 \text { (United } \\
\text { Bank ltd- }\end{array}$ & $\begin{array}{l}\text { Average } \\
\text { Abnormal Return }\end{array}$ & $-3.03 \%$ & $-0.24 \%$ & $-0.08 \%$ & $0.15 \%$ \\
\hline $\begin{array}{l}\text { Khushhali Bank } \\
\text { Limited) }\end{array}$ & $\begin{array}{l}\text { Cumulative } \\
\text { Abnormal Return }\end{array}$ & $-13.61 \%$ & $-10.58 \%$ & $-3.77 \%$ & $6.81 \%$ \\
\hline
\end{tabular}

\subsection{Long Term Analysis}

The combination gain and to achieve synergy benefits is depend on the amalgamation process and this may require more times for firms to be effective[17]. So, to analyze the long run 
effect of events we have extended this study by observing the long term effects on the stock prices. So, the author measured the performances of stocks for 90, 180, 270 and 230 days separately. This was measured after the announcement of deals using the Buy-and-Hold Abnormal Returns (BHAR) Approach. Below table shows the results of this long-term analyses using BHAR technique. We found that after 360 days the BHAR decreased by $23.82 \%$ and $-6 \%$ for the event 2 and 5 respectively both events are insignificant at the $5 \%$ level. Further, for the event1, 3 and 4 BHAR increased by the $12 \%, 10 \%$, and $3 \%$ respectively from these three events, the event 1 and 3 are highly significant at the 5\% level and the event 4 is insignificant at the $5 \%$ level.

Table 3 BHAR for 90, 180, 270 and 360 days

\begin{tabular}{|c|c|c|c|c|c|}
\hline Event & & $\begin{array}{c}\text { BHAR } 90 \\
\text { days }\end{array}$ & BHAR180 days & $\begin{array}{c}\text { BHAR } 270 \\
\text { days }\end{array}$ & $\begin{array}{c}\text { BHAR } 360 \\
\text { days }\end{array}$ \\
\hline $\begin{array}{l}\text { Event } 1 \text { (MCB } \\
\text { Bank Ltd- NIB } \\
\text { Bank ltd) }\end{array}$ & $\begin{array}{l}\text { Buy-and-Hold } \\
\text { Abnormal } \\
\text { Return }\end{array}$ & $9 \%$ & $7 \%$ & $5 \%$ & $12 \%$ \\
\hline $\begin{array}{l}\text { Event } 2 \text { (Meezan } \\
\text { Bank Ltd- HSBC } \\
\text { Oman (Pakistan } \\
\text { operations)) }\end{array}$ & $\begin{array}{l}\text { Buy-and-Hold } \\
\text { Abnormal } \\
\text { Return }\end{array}$ & $-10 \%$ & $-35 \%$ & $-15 \%$ & $-23.82 \%$ \\
\hline $\begin{array}{l}\text { Event } 3 \text { (Bank } \\
\text { Islami Pakistan } \\
\text { Ltd- KASB Bank } \\
\text { Ltd) }\end{array}$ & $\begin{array}{l}\text { Buy-and-Hold } \\
\text { Abnormal } \\
\text { Return }\end{array}$ & $4 \%$ & $5 \%$ & $17 \%$ & $10 \%$ \\
\hline $\begin{array}{l}\text { Event } 4 \text { (Meezan } \\
\text { Bank Ltd -HSBC } \\
\text { Bank Middle East } \\
\text { Limited (Pakistan } \\
\text { operations)) }\end{array}$ & $\begin{array}{l}\text { Buy-and-Hold } \\
\text { Abnormal } \\
\text { Return }\end{array}$ & $-2 \%$ & $-9 \%$ & $3 \%$ & $3 \%$ \\
\hline $\begin{array}{l}\text { Event } 5 \text { (United } \\
\text { Bank ltd- } \\
\text { Khushhali Bank } \\
\text { Limited) }\end{array}$ & $\begin{array}{l}\text { Buy-and-Hold } \\
\text { Abnormal } \\
\text { Return }\end{array}$ & $-15 \%$ & $-7 \%$ & $-20 \%$ & $-6 \%$ \\
\hline
\end{tabular}

\section{CONCLUSION AND RECOMMENDATIONS}

Mergers and acquisitions trend in Pakistan can be traced back from 1998, from then and there numerous events occurred in Pakistan gradually every year. The same trend can be seen in the financial sector of Pakistan [18]. Synergy theory discuss that the companies go for M\&As with an intention to growth, reduce costs, acquire assets and for the expansion of business in new markets to improve profitability and to enhance wealth of shareholders[19].

The purpose of this paper was to analyze the performance of banking sector firms of Pakistan in terms of shareholders' wealth after the occurrence of M\&As. This was done in two ways; first, short term performance was analyzed with the help of event study method to interpret abnormal returns after the M\&As. Secondly, Long term performance was analyzed with the help of BHAR, as per different authors, such events of M\&As take a longer time to mature. This study show that the M\&As occurrence in banking sector had significant and positive impact on the shareholders' wealth so this can be concluded for the banking sector of Pakistan that it has potential to achieve synergistic gain, improving the returns and performance of firms. This study suggests that, various other studies can be conducted to analyze the financial stability of various sectors by using accounting method so that financial 
ratios can be analyzed and managerial perspective can be analyzed as well in various sectors of the country.

\section{REFERENCES}

[1] Dutta S, Jog V. The long-term performance of acquiring firms: A re-examination of an anomaly. Journal of Banking \& Finance. 2009;33(8):1400-12 DOI: https://doi.org/10.1016/j.jbankfin.2009.02.004.

[2] Alao RO. Mergers and Acquisitions (M\&As) in the Nigerian Banking Industry: An Advocate of three Mega Banks. European Journal of Social Sciences. 2010;15(4):554-63.

[3] McShane SL, Von Glinow MA. Organizational behavior: McGraw-Hill/Irwin; 2004.

[4] Georgios K, Georgios H. Du Pont Analysis of a Bank Merger and Acquisition between Laiki Bank from Cyprus and Marfin Investment Group from Greece. Is there an increase of profitability of the new bank? Kyriazopoulos-Hadjimanolis, MIBES 2011-Oral. 2011:157-76.

[5] Gattoufi S, Al-Muharrami S, Al-Kiyumi A. The impact of mergers and acquisitions on the efficiency of GCC banks. Banks and Bank Systems. 2009;4(4):94-101.

[6] Goddard J, Molyneux P, Zhou T. Bank mergers and acquisitions in emerging markets: evidence from Asia and Latin America. The European Journal of Finance. 2012;18(5):419-38.

[7] Wright M, Filatotchev I, Hoskisson RE, Peng MW. Strategy research in emerging economies: Challenging the conventional wisdom. Journal of management studies. 2005; 42(1):1-33.

[8] Bashir A, Sajid R, Sheikh S. The impact of mergers and acquisitions on shareholders wealth: evidence from Pakistan. Journal of Scientific Research. 2011;8(1):261-4.

[9] Ahmed M, Ahmed Z. Mergers and acquisitions: Effect on financial performance of manufacturing companies of Pakistan. Middle-East Journal of Scientific Research. 2014; 21(4):689-99.

[10] Mahmood I, Aamir M, Hussain CM, Sohail N. Impact of merger/acquisition on share price-a case study of Pakistan. European Journal of Scientific Research. 2012;67(4):617-24.

[11] Rahman Z, Ali A, Jebran K. The effects of mergers and acquisitions on stock price behavior in banking sector of Pakistan. The Journal of Finance and Data Science. 2018;4(1):44-54.

[12] Corrado CJ. Event studies: A methodology review. Accounting \& Finance. 2011; 51(1):20734 DOI: [https://doi.org/10.2139/ssrn.1441581.

[13] Sharma M. Determining value creation through mergers and acquisitions in the banking industry using accounting study and event study methodology. European Journal of Economics, Finance and Administrative Sciences. 2010;19:61-73.

[14] Flugt C. Shareholder wealth effects of mergers and acquisitions: An empirical investigation of short-term performance in the European market. Aarhus School of Business, University of Aarhus, Aarhus, Denmark, working paper. 2009.

[15] Soongswang A. Total gains: do mergers and acquisitions pay investors in the event firms? Asian J Bus Manag Sci. 2011;1:136-49 DOI: https://doi.org/10.2139/ssrn.1867854.

[16] Cummins JD, Weiss MA. Consolidation in the European insurance industry: do mergers and acquisitions create value for shareholders? Brookings-Wharton Papers on Financial Services. 2004;2004(1):217-58 DOI: https://doi.org/10.1353/pfs.2004.0001.

[17] Hakkinen L, Hilmola O-P. Integration and synergies of operations in horizontal M\&A. International journal of management and enterprise development. 2005;2(3-4):288-305 DOI: https://doi.org/10.1504/ijmed.2005.006563.

[18] Tauseef S, Nishat M. Wealth Effect of Mergers \& Acquisitions In Emerging Market: A Case Of Pakistan's Banking Sector. IBA Business Review. 2014; 9(2) DOI: https://doi.org/10.2139/ssrn.1653690.

[19] Martynova M, Renneboog L. Mergers and acquisitions in Europe. Advances in corporate finance and asset pricing2006. p. 13-75. 